\title{
Antinomism in Twentieth-Century Russian Philosophy: The Case of Pavel Florensky
}

\author{
Harry James Moore ${ }^{1}$ (D)
}

Published online: 20 August 2020

(c) The Author(s) 2020

\begin{abstract}
This study examines the notion of antinomy, or unavoidable contradiction, in the work of Pavel Florensky (1882-1937). Many Russian philosophers of the Silver Age shared a common conviction which is yet to receive sufficient attention in critical literature, either in Russia or abroad. This is namely a philosophical and theological dependence on unavoidable contradiction, paradox, or antinomy. The history of antinomy and its Russian reception is introduced here before a new framework for understanding Russian antinomism is defended. This is namely the anticipation of 'vertical' antinomies in 'horizontal' antinomies. Here, by 'horizontal' we suppose an unavoidable contradiction of reason or philosophical reflection, and by 'vertical' an unavoidable contradiction of revelation, faith, or a self-contradictory dogma. The study aims to demonstrate that Florensky fails to provide a satisfactory anticipation of vertical antinomies.
\end{abstract}

Keywords Antinomy $\cdot$ Paradox $\cdot$ Pavel Florensky $\cdot$ Contradiction

Den Satz des Widerspruchs zu vernichten, ist vielleicht die höchste Aufgabe der höhern Logik - Novalis.

The Russian Silver Age nurtured a philosophically charged "religious consciousness" amongst many of its protagonists, which would be triumphantly received by Nicholas Zernov as the "Russian Religious Renaissance" (Zernov 1963). ${ }^{1}$ This renaissance was not instantaneous of course and can, in fact, be traced back to the great philosopher, poet and mystic Vladimir Solov'ev (1853-1900), ${ }^{2}$ and even

\footnotetext{
1 For a historical introduction to this "renaissance" see also: Coates (2010).

2 Vladimir Solov'ev is still considered by many as the father of Russian philosophy, and is most renowned for his Lectures on Godmanhood. Here he establishes one of the defining features of Russian religious thought, the notion of all-unity (vseedinstvo). This notion (originally adapted from F.W.J. Schelling's "All-Einheit") is a sort of integralism, whereby all facts of life are brought into correct rela-
}

Harry James Moore

harry.moore@bnc.ox.ac.uk

1 University of Oxford, Oxford, UK 
further back to the controversies between the Slavophiles and the Westernizers (Khoruzhi 2010). Some of the most influential thinkers of this renaissance included Pavel Florensky (1882-1937), Sergei Bulgakov (1871-1944), and Aleksei Losev (1893-1988). These three thinkers were all firmly rooted in this broad school and were in close contact during the years leading up to and shortly following the 1917 revolution.

These erudite men shared a common conviction which is yet to receive sufficient attention in critical literature, either in Russia or abroad. This is namely a philosophical and theological dependence on unavoidable contradiction, paradox, or "antinomy". ${ }^{3}$ Florensky, Bulgakov and Losev all used antinomies to construct elaborate philosophical and theological systems. The present study will undertake an analysis and critical evaluation of Pavel Florensky's antinomism. This will demonstrate that Russian antinomism could only reach philosophical maturity in the anticipation of "horizontal" antinomies in "vertical" antinomies. Here, by "horizontal" we suppose an unavoidable contradiction of reason or philosophical reflection, and by "vertical" an unavoidable contradiction of revelation or a self-contradictory dogma (this terminology is defined in more detail below). Certainly, the three thinkers mentioned above are not the only Russian thinkers to rely heavily on antinomy and paradox. An antinomian disposition is a defining mark for various Russian philosophers, notably Lev Shestov (1866-1938), ${ }^{4}$ Semyon Frank (1877-1950), ${ }^{5}$ Boris Vysheslavtsev (1877-1954), ${ }^{6}$ Lev

\footnotetext{
Footnote 2 (continued)

tion with an Absolute centre (without forfeiting their multiplicity), and are thereby brought into correct relation with one another. Solov'ev writes: "A separately taken fact, an individual phenomenon, obviously does not represent the truth by itself, in its detachment, but is acknowledged only as true in a normal relation, in a logical connection, or accord with the whole". This whole (vse) is something more than the sum of its parts and therefore cannot be considered mechanistically but is accessible only via "immediate perception" which is "religious knowledge" (Solov'ev 1948a, b, pp. 73-74).

3 Sergei Astapov gives a brief comparison of the antinomism of Bulgakov, Florensky and Frank (Astapov 2009), See also Ksana Blank's (2007) contribution, discussed below in more detail.

${ }^{4}$ Lev Shestov is one of the twentieth century's most celebrated 'anti-rationalists'. For an introduction to Shestov's 'paradoxality of thought' see Berdyaev (1938).

5 Frank, in his The Unknowable: An Ontological Introduction to the Philosophy of Religion developed an approach which he called "antinomian monodualism" as a sort of mediation between identity and difference. We read: "With this we arrive at a conclusion of the greatest significance; namely, that the only adequate ontological framework for wise ignorance, insofar as it is expressed in antinomical knowledge, is antinomian monodualism. It does not matter what logically graspable opposites we have in mind: unity and diversity, spirit and flesh, life and death, eternity and time, good and evil, Creator and creation. In the final analysis, in all these cases the logically separate, based on mutual negation, is inwardly united, mutually permeating; in all these cases the one is not the other but it also is the other; and only with, in, and through the other is it what it genuinely is in its ultimate depth and fullness. This makes up the antinomian monodualism of everything that exists; and in the face of this monodualism every monism and every dualism are false, simplifying, distorting abstractions, which are not able to express the concrete fullness and concrete structure of reality" (Frank 1983, p. 97).

6 Vysheslavtzev's antinomism differentiates between the "war-like" contradictions among men (with echoes of Hobbes) and the "harmony of contradictions" which comes through an embrace of antinomy. The first approach is meaningless since it is perpetually (and violently) trying to remove the contradiction, the second is a "holy marriage of elements" and a mysterious tertium quid, a "harmony of poles" which forms the basis for the "hierarchic structure of being, from atom to cell, from animated life to the living spirit, with all their new conflicts and resolutions" (Vysheslavtzev 1994, p. 237).
} 
Karsavin (1882-1952), ${ }^{7}$ and Nikolai Berdyaev (1874-1948). ${ }^{8}$ Thinkers such as these will be addressed where appropriate, although their concerns with antinomy and paradox lack the self-conscious organisation which is found, for example, in Florensky, Bulgakov and Losev.

The history of antinomy will first be introduced (1.0), and the terminological distinction of "vertical" and "horizontal" antinomism clarified and defended (1.1), before Florensky's thought itself is addressed (2.0). Here we will assess the most prevalent readings of Florensky's philosophy, including his highly problematic logical theory of antinomy (2.1). We will then examine the somewhat more promising antinomy of the laws of identity and sufficient reason, which was to serve as an anticipation of the Trinity (2.5). Finally, it will be suggested that Florensky was justified in maintaining dogmatic antinomies (namely the Trinity) as real contradictions (2.6). It will, however, ultimately be demonstrated that Florensky failed to provide an anticipation of the vertical antinomy of the Trinity in the horizontal antinomies of logic. For a more successful anticipation of vertical antinomies, one ought to address the contributions of Bulgakov and Losev, a task which falls outside the remits of the current paper.

\section{The Origins of Russian Antinomism}

According to a basic encyclopaedia definition, antinomy (Greek $\alpha \nu \tau 1-$, against, plus

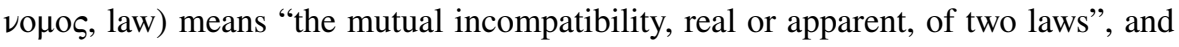
is a term "often used in logic and epistemology, when describing a paradox or unresolvable contradiction". ${ }^{9}$ Unresolvable contradictions have a long and rich history in philosophy and logic. ${ }^{10}$ Although paradox and contradiction already played a particular role in pre-Socratic thinkers, it was certainly Plato who would become the most antinomic of ancient philosophers. ${ }^{11}$ Plato's dialogues, for instance, often end

\footnotetext{
7 Karsavin was particularly occupied with the antinomies of corporeal life. The fact that we possess our own corporeality individually, whilst sharing it with the universal embodiment of human nature in general was an unresolvable antinomy for Karsavin. See: Zenkovsky (1953, p. 848), Lossky (2018, p. 442).

8 According to Berdyaev, "Religious life is essentially antinomic; it encompasses in itself theses, which seem incompatible and contradictory to reason, and mystically (tainstvenno) overcomes these contradictions. The antinomism of the transcendental and immanent is unsolvable and unbridgeable rationally; it can be defeated in religious experience and can be overcome in it. The contradictions are reconciled in the highest spiritual enlightenment (vyschee ozarenie)" (Berdyaev 1989, p. 556).

9 'Antinomy' in New World Encyclopedia (2016) [https://www.newworldencyclopedia.org/entry/Antin omy].

10 Florensky himself provides a short history of the term "antinomy" as an appendix of his magnum opus, The Pillar and Ground of the Truth: An Essay in Orthodox Theodicy in Twelve Letters (Florensky 1997, p. 411). Quotations will be taken from Boris Jakim's translation unless otherwise stated. The Russian referred to here is from the original 1914 publication (Florensky 1914).

11 In Florensky's reading, "A great proponent of the antinomical-ness of rationality (though he is still not understood in this aspect) was Plato. The majority of his dialogues are nothing but a gigantic antinomy, developed with all care and artistically dramatized... nearly every one of the dialogues only sharpens the contradiction and deepens the abyss between "yes" and "no", between thesis and antithesis". "Velikim, khotia do sikh por s etoi storony neponiatym, storonnikom antinomichnosti rassudka byl i sam Platon. Bol'shinstvo ego dialogov - ne inoe chto, kak ispolinskie, so vseiu tschatel'nost'iu razvitye i khudozhest-
} 
in an aporia ( $\dot{\alpha} \pi \circ \rho i \alpha)$, a state of puzzlement where previously held beliefs are cast into an unresolved tension. ${ }^{12}$ Antinomy is even touched on as a point of 'ascent' to a noetic realm. In Book VII of the Republic Glaucon asks: "What would be apt to summon or stimulate noetic activity?" (Plato 1997, p. 523e). Socrates then responds by demonstrating that his fourth finger (ring finger) is paradoxically both large (when compared with his little finger) and small (when compared with his middle finger). Bruce Foltz comments on this passage with the following: "This contradiction in the visible realm... is precisely what he [Plato] maintains is able to stimulate and awaken the noetic intellect to go beyond the visible to what is intelligible, but not visible: to make the transition from one world to another" (Foltz 2013, p. 12). ${ }^{13}$ Therefore, already in Plato can contradiction be read as "anticipating" a higher realm or mode of being.

Although classical logic since Aristotle has maintained the four laws of logic (Non-Contradiction, Identity, Excluded Middle, and Sufficient Reason) as orthodoxy, many thinkers have reformulated them or rejected them in the history philosophy. The late Middle Ages especially saw such reformulations and re-evaluations of contradiction, the key example being Nicholas of Cusa (1401-1464). Cusa is responsible for the coincidentia oppositorum, or "coincidence of opposites", which assumes the co-existence of two opposing but equally necessary statements. For example, in De Docta Ignorantia, Cusa relies on the co-existence of the "maximum" and the "minimum": "For maximum quantity is maximally large; and minimum quantity is maximally small. Therefore, if you free maximum and minimum from quantity, by mentally removing large and small, you will see clearly that maximum and minimum coincide" (Nicholas of Cusa 1981, p. I, 4). Importantly, according to Cusa's coincidentia oppositorum, the "coincidence" (or antinomy) is never resolved, even in God. As Marko Usric has shown, "Contradictions in God, according to Cusa, remain contradictions, they do not disappear simpliciter, for in God, opposition and non-opposition of contradictions coincide" (Usric 1998, p. 214). In other words in God the antinomy remains but now as an antinomy between 'antinomism' and 'non-antinomism'. Antinomies are present both in the world (horizontally) and in God (vertically).

It is however Immanuel Kant (1724-1804) with whom the term antinomism is most famously associated. Kant was the first to be consciously and systematically

\footnotetext{
Footnote 11 (continued)

venno dramatizirovannie antinomii... chut' li ni kazhdyi dialog lish' obostriaet protivorechie i uglubliaet bezdnu mezhdu "da" i "net", mezhdu tezisom i antitezisom" (Florensky 1914, p. 156).

12 For example, in the Charmides, Socrates leaves us with the aporia that there is a "science of science" but that it is all the same useless. (Cohen 1962, p. 167).

13 Florensky laments that Plato's antinomism is largely unnoticed by commentators. This is, of course, no longer the case. Verity Harte, for instance, shows how the visible and temporal counterparts to Platonic forms are characterised by a "compresence of opposites", which holds that "it would be true to say of some subject both that it is F and that it is un-F (the opposite of F)" (Harte 2008, p. 202). Harte then gives the example of Socrates' reflection on the form "Equal" in the Phaedo (74d4-8): "Socrates and Simmias agree that equal sticks are both equal and unequal (albeit in different respects); they may, for example, be equal in length but not in weight; equal to each other but not to some third stick of different dimensions" (Harte 2008, pp. 202-203).
} 
aware of a philosophy of contradictions. As Bulgakov admits, "Kant's merit is not that he noticed this antinomical quality, for philosophical thought has essentially been dealing with it for as long as one can remember; but rather that he was aware of it so acutely" (Bulgakov 1994, p. 133). In his Critique of Pure Reason, Kant presents a series of four antinomies. These antinomies were of a cosmological and metaphysical nature. Such antinomies arise, in Kant's view, through the inappropriate application of the categories of the understanding to the noumenal realm. Kant writes in The Critique: "If we apply our reason, not merely to objects of experience, in order to make use of the principles of the understanding, but venture to extend it beyond the limits of experience, then there arise sophistical doctrines, which may neither hope to be confirmed nor fear to be refuted in experience. Every one of them is not only in itself free from contradiction, but can even point to conditions of its necessity in the nature of reason itself_-although, unfortunately, the assertion opposing it can produce equally valid and necessary grounds in its support" (Kant 1956, B449 A421). ${ }^{14}$

The first of such antinomies takes as its thesis the following: "The world has a beginning in time and is limited as regards space" (Kant 1956, B454 A426). ${ }^{15}$ Kant employs a reductio ad absurdum and reasons that "an infinite past series of the world is impossible" (B454 A426). ${ }^{16}$ This is because the infinite series is unintelligible as it cannot be completed "by means of a successive synthesis" (B455 A472). ${ }^{17}$ Likewise, in terms of space: "We cannot conceive the magnitude of a quantum which is not given within certain limits of intuition" (B455-456 A472-473). ${ }^{18}$ In order to think the world, therefore, "the successive synthesis of the parts of an infinite world would have to be looked upon as completed... this is impossible" (B456 A428). ${ }^{19}$ The world cannot be spatially infinite. However, Kant's antithesis then reads as follows: "The world has no beginning and no limits in space, but is infinite (unendlich) as regards both time and space" (B455 A427). ${ }^{20}$ Kant now reasons, once again by reductio ad absurdum, that "a beginning is an existence preceded by a time in which

\footnotetext{
14 "Wenn wir unsere Vernunft nicht bloß, zum Gebrauch der Verstandesgrundsätze, auf Gegenstände der Erfahrung verwenden, sondern jene über die Grenze der letzteren hinaus auszudehnen wagen, so entspringen vernünftelnde Lehrsätze, die in der Erfahrung weder Bestätigung hoffen, noch Widerlegung fürchten dürfen, und deren jeder nicht allein an sich selbst ohne Widerspruch ist, sondern sogar in der Natur der Vernunft Bedingungen seiner Notwendigkeit antrifft, nur daß unglücklicher Weise der Gegensatz ebenso gültige und notwendige Gründe der Behauptung auf seiner Seite hat." Kant's German is taken from (Kant 1956, B449 A421). Unless otherwise stated, English translations will be taken from (Kant 2007).

15 "Die Welt hat einen Anfang in der Zeit, und ist dem Raum nach auch in Grenzen eingeschlossen".

16 "Also ist eine unendliche verflossene Weltreihe unmöglich".

17 "Nun besteht aber eben darin die Unendlichkeit einer Reihe, daß sie durch sukzessive Synthesis niemals vollendet sein kann".

18 "Nun können wir die Größe eines Quanti, welches nicht innerhalb gewisser Grenzen jeder Anschauung gegeben wird, auf keine andere Art, als nur durch die Synthesis der Teile... gedenken".

19 "Die sukzessive Synthesis der Teile einer unendlichen Welt [müßte] als vollendet angesehen [werden]... welches unmöglich ist".

20 "Die Welt hat keinen Anfang, und keine Grenzen im Raume, sondern ist, sowohl in Ansehung der Zeit, als des Raums, unendlich".
} 
the thing is not" (B456 A428). ${ }^{21}$ For this reason, it would seem that before the world there was nothing, just an empty time. However, nothing can arise in empty time as no part of that time is more conducive to existence than any other, there is no "distinguishing condition of existence" (B456 A428). ${ }^{22}$ Kant concludes that the world as a whole is temporally infinite. Similarly, as regards space, "there can be no object of intuition outside the world", which is an "absolute whole" (B457 A429). ${ }^{23}$ Since the relation between the world and empty space would just be nothing, the world must also be spatially infinite.

This antinomy, along with the other three antinomies of pure reason: the existence of composite and simple parts; causality and freedom; and the existence of a first principle (God), are posed by Kant as Grenzbegriffe, that is, limits on our knowledge of things which leave reason in a "state of constant oscillation" (B503). ${ }^{24}$ Such antinomies are sophistical illusions which are created by pure reason and signify that we have no epistemological access to the noumenal object in question. Reason has a built-in desire for unconditional unity which eventually forces it into such antinomies when it attempts to cognize aspects of the noumenal realm (e.g. the universe, God, the soul).

Antinomies do not fade in significance throughout the development of German Idealism. A noteworthy contribution is made by G. W. F. Hegel (1770-1831). Hegel famously critiques the closed-off realm of the noumena and the Kantian thing-initself and thus, instead of seeing antinomies as Grenzbegriffe like Kant, interprets them positively, as the force behind his dialectical reasoning. Antinomies no longer consist only in Kant's four "antinomies of pure reason" but are universal for Hegel, who writes: "The true and positive meaning of the antinomies is this: that every actual thing involves a coexistence of opposed elements. Consequently, to know, or, in other words, to comprehend an object is equivalent to being conscious of it as a concrete unity of opposed determinations" (Hegel 1975, §48). Hegel's dialectic in the Logic, which constructs philosophy's most elaborate system of all-inclusive categories, proceeds by way of contradictions which are discovered and then annulled (aufgehoben) as we move on to the next category. The first example Hegel gives concerns "being". Since authentic being can only be determinate and pure being coincides with its opposite (nothing), the general concept of 'being' is negated. As Charles Taylor puts it, "our dialectical argument, by showing a contradiction in 'being' deduces the next category (in this case, 'determinate being')" (Taylor 1975, p. 229). Aleksei Losev's methodology, for instance, is famous for appropriating this Hegelian dialectic, but in a yet more antinomic fashion.

Alongside German Idealism, native Russian tendencies towards the embrace of contradiction provide a closer context for the philosophers in question. The

\footnotetext{
21 'Der Anfang ist ein Dasein, wovor eine Zeit vorhergeht, darin das Ding nicht ist'.

22 'Eine unterscheidende Bedingung des Daseins'.

23 'Die Welt [ist] ein absolutes Ganzes, außer welchem kein Gegenstand der Anschauung... angetroffen wird'.

24 'Ein unaufhörlich schwankender Zustand'.
} 
specifically Russian approach to contradiction was already religious in its scope. The poet and writer Fyodor Tyutchev (1803-1873), for example, wrote that "Man ought to believe as the apostle Paul and as Blaise Pascal believed, by bowing their knee at the contradictions of the cross, or else must deny everything" (Florovsky 1998, p. 235). Another great literary figure, Fyodor Dostoyevsky (1821-1881) focused on the "dialogic opposition" between good and evil. As Mikhail Bakhtin (1895-1975) reads him: "Everything in the novel is structured to make dialogic opposition unresolvable (bezyskhodnoe)" (Bakhtin 1984, p. 18). In this regard, Ksana Blank comments as follows: "The pros et contras involved in this eternal dialogue form a single, antinomic Truth" (Blank 2007, p. 24). Blank's paper is the closest in scope to the present study and examines Dostoyevsky's antinomism comparatively within the context of Russian religious thought. Surprisingly, Losev's and Bulgakov's antinomies, along with their function in a developed philosophy of religion, are not examined by Blank. More importantly, Blank fails to uncover the spiritual drive of Russian antinomism, which aims for the anticipatory referral from horizontal antinomies of reason to vertical antinomies of faith (such as the Trinity), thus providing justification for the latter. This sort of conceptual anticipation demands some further analysis.

\section{The Anticipation of the 'Vertical' in the 'Horizontal'}

This distinction between two types of antinomy is not arbitrary, but makes perfect sense when we consider what sort of antinomies there are. By horizontal antinomy we will suppose any antinomy or unavoidably 'true contradiction' as it presents itself in immediate and freely accessible givenness. These are the sorts of antinomies which we find for example in formal logic, as purely 'logical paradoxes' which can be reduced to $(\alpha \wedge \neg \alpha)$. Besides logic, such antinomies might also include the internal paradoxes of ontology, aesthetics, linguistics and subjectivity. Florensky, Bulgakov, and Losev are certainly aware of such antinomies, although the extent to which they are employed as anticipating 'higher antinomies' varies significantly. These 'higher' antinomies, or vertical antinomies, are those which are traditionally understood as revealed truths. These antinomies are only worth talking about once the common discourse of a 'religious consciousness' or theology has been adopted. One might include here (as many theologians have done) the paradoxes of God's relationship with His creation (which must be both dependent on, and independent from God), of God's Triune existence, or of the dual natures of Christ. Countless scriptural and liturgical antinomies also fall under this category.

In order for these latter antinomies to be given some epistemic justification, corresponding anticipatory horizontal antinomies must first be constructed. In other words, the subject must be saturated in an inexhaustible antinomian reality, where objective paradoxes are consistently apprehended as anticipating higher paradoxes, receiving their fullest meaning in these higher paradoxes. This anticipation is no simple entailment or deduction of theology from philosophy, of faith from reason, but by virtue of its paradoxical nature is a metanoia or a living induction which is not logically deduced but rather "anticipated" through a demonstration that antinomies 
receive their truest expression in Christian dogma and religious life. The suggestion that the structure of reality points to and anticipates the Trinity was a key conviction in twentieth-century theology. According to Klaus Hemmerle (1929-1994) and his Thesen zu einer trinitarischen Ontologie (first published in 1976), the "ordering of creation is an anticipation (Vorläufigkeit) of its Trinitarian fulfilment and completion" (Hemmerle 1992, p. 59).

This anticipatory approach receives significant warrant, when we consider that we make similar "anticipations" in our everyday perception of the external world. We can learn, for example, from Husserl's phenomenology that there is, as Joel Smith comments, a "Reference from the 'genuinely perceived' sides of the object of perception to the sides 'also meant' - not yet perceived, but only anticipated" (Smith 2020). ${ }^{25}$ Similarly, an "intentional awareness of the future event as about to happen", or in Husserl's terminology "protention" (Husserl 1991, p. 40), forms the basis for the consistent stream of consciousness. Anticipation is thus a spatiotemporal prerequisite, or in Kantian terminology a "regulative principle", which must be in place for a coherent organisation of the world. Despite this warrant for "anticipating" belief in the Trinity, the present method should be distinguished from an apparently rational deduction of the Trinity. The latter is exemplified in the work of Vladimir Solov'ev, whose trinitarianism has been read as "a highly rationalist philosophy... where God necessarily generates or posits Himself” (Gallaher 2012, p. 209). For Solov'ev, the Trinity can be "logically deduced from the admission that God is". This is because being has three simultaneous moments: (1) existence as actuality (2) activity/expression and (3) awareness and enjoyment of the subject's own being (Solov'ev 1948a, b, p. 142). However, in the present case, the very material of our argumentation is already paradoxical and therefore the argument as a whole escapes the condemnation of being such a "rationalist deduction".

Much of early twentieth-century Russian philosophy attempted to make such anticipations between horizontal and vertical antinomies. Only Pavel Florensky, however, attempts an anticipation through formal logic alone and attempts to reveal the 'antinomicity' of truth itself. According to this counter-intuitive claim, the most antinomian and paradoxical statements of all (those of Christian dogma), are therefore the truest. This was by no means an uncontroversial project. However, the success or failure of this project should not detract from the appreciation of Russia's great polymath and religious thinker to whom we now turn.

\section{Pavel Florensky and Antinomian Truth}

Pavel Aleksandrovich Florensky (1882-1937) is gradually being recognised as one of the most remarkable figures of twentieth-century intellectual history. Mathematics, engineering, biology, philosophy, linguistics, art history, aesthetics and theology were all subject areas in which Florensky excelled. ${ }^{26}$ The origins of Pavel

\footnotetext{
25 Smith is relying here on Husserl's Cartesian Meditations (Husserl 1960).

26 A full biography in English is provided by Pyman (2010).
} 
Florensky's antinomism can be traced back to a lecture he gave in 1908, "The Cosmological Antinomies of Immanuel Kant" (Florensky 1996c). Florensky had for a long time expressed an intuitive repulsion to Kantian philosophy. He writes: "The Kantian separation of noumena and phenomena (even when I had no suspicion of the existence of any one of these terms: 'Kantian', 'separation', 'noumena' and 'phenomena') I rejected with all my being” (Florensky 2010, p. 9). Indeed, such a separation doesn't agree with the Russian thinker's conviction of the real and accessible extra-conceptual world. What Florensky recognised as "the main intuition of the human race" is that "I live in the world and with the world, which implies the being, and the real being, both of me, the human, and of that what is outside me, what exists separately, and more exactly, independently of human consciousness" (Florensky 1996b, p. 283).

In his lecture on Kant, Florensky examines the antinomies found in The Critique of Pure Reason. Florensky first expresses great admiration for Kant's sensitivity for antinomy: "The idea of the possibility of antinomies of reason is the deepest and most fruitful of all Kant's ideas" (Florensky 1996c, p. 28). He then went on, however, to claim that Kant's famous antinomies are not true antinomies, because they can be reduced to mere "functions of consciousness" (Florensky 1996c, p. 27). Kant's antinomies differ from Florensky's, since for Kant the antinomy marked the boundary of experience, a frustrating limit to our knowledge, stopping us short of the apprehension of a hidden noumenal truth. As Florensky writes, "At the heart of Kant's deductions lies his differentiation between the thing-in-itself and the phenomena" (Florensky 1996c, p. 27). The antinomies mark the end of the phenomenal and the start of the noumenal. This means that Kant's antinomies are already conditioned by a certain epistemology. For Florensky, however, antimony is the unconditioned objective Truth itself. This is a difficult notion which must be elucidated by a closer analysis of Florensky's monumental work, The Pillar and Ground of the Truth.

Despite its many theological critiques, ${ }^{27}$ The Pillar has been hailed as "the most important sustained inquiry into the theology of the Christian Trinity since Chalcedon" (Foltz 2013, p. 6), containing a nuanced and rich philosophical defence of Trinitarian dogma. In the early chapters of the book, Florensky formulates a key distinction between rationality (rassudok) and reason (razum), to which he subordi-

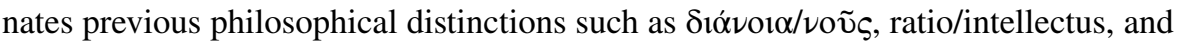
Verstand/Vernunft. Horizontal antinomism characterises the former, while vertical antinomism belongs to the latter. A bold attempt is made to pass from the former to the latter by showing that truth in and of itself is an antinomy (which would make vertical antinomic dogmas necessarily true in virtue of their contradictoriness). This is initially formulated in a turn to symbolic logic, known as the "formal logical theory of antinomy" (Florensky 1914, p. 148). ${ }^{28}$

\footnotetext{
27 The most famous of such critiques is found in Florovsky (1989).

28 "Formal'naia logicheskaia teoriia antinomii".
} 


\section{The 'Logical' Theory of Antinomy}

Although this theory (as presented in Letter Six of The Pillar, 'Contradiction') is now widely discredited, it provides an introduction to the author's more convincing antinomy between the laws of Identity and Sufficient Reason. Florensky claims that since any thesis presupposes its antithesis (and vice versa) we should not be satisfied with choosing between either thesis or antithesis, but rather should paradoxically accept both the thesis and the antithesis. In other words, any truth presupposes and includes within itself the potential of its negation, and is thus one with its negation. ${ }^{29}$ Here, Florensky has already departed from Solov'ev for whom "the Truth", as all-unity, "cannot contradict itself" (Solov'ev 1948a, b, p. 84). For Florensky, however, "symbolic logic explains and even justifies a paradoxical method of reasoning" (Florensky 1914, p. 150). ${ }^{30}$ Following the Italian mathematician Giovanni Vailati (1863-1909), Florensky asserts that "the negative of a proposition implies the proposition that it negates" (Florensky 1914, p. 150). ${ }^{31}$

\section{(1) $(\neg p \rightarrow p) \rightarrow p$}

Florensky then deduces the opposite formula. (That a thesis entails its antithesis):

$$
(\mathrm{p} \rightarrow \neg \mathrm{p}) \rightarrow \neg \mathrm{p}
$$

Florensky then proves these respective formulas, which are in fact simple tautologies of classical logic. No real logical conclusion can thus be drawn from the initial opposition, since the tautologies need not have any relation with one another. As Pawel Rojek confirms, "The logical argument is plainly obsolete. Florensky simply proved the principle of reductio ad absurdum in two different forms. The principles are tautologies of propositional calculus and together cannot form a contradiction" (Rojek 2019, p. 124). Although there are obvious problems with Florensky's reasoning here, we should not underestimate his understanding of symbolic logic. As Biriukov observes, "Although he mastered logical technique, he did not really think through the problem of how to combine the logical calculus with his own theological position" (Biriukov 2010, p. 55). Even though Florensky's efforts to understand all truths as inherently paradoxical seems to be a failure, this does not invalidate the fact that there might be some necessary logical contradictions. The real question,

\footnotetext{
${ }^{29}$ In a telling passage Florensky elucidates this claim with the following: "In effect, the existence of the thesis in no way guarantees the nonexistence of the antithesis; on the contrary it always presupposes the existence of the antithesis in the domain of the spirit and often presupposes it in other domains". What Florensky refers to as "the domain of the spirit" is clearly "the vertical" in our terminology, with "other domains" being "the horizontal". "Ved' nalichnost' tezisa niskol'ko ne obespechivaet nesuschestvovanie antiteza, a, - po kraine mere $\mathrm{v}$ oblasti dukha vsegda, a v inykh oblastiakh chasto -, predpolagaet nalichnost' antitezisa" (Florensky 1914, p. 152).

30 "Logistika ob' 'iasniaet i opravdyvaet etot paradoksal'nyi sposob rassuzhdeniia".

31 "Esli negativ predlozheniia (ili sootvetstvenno, klassa) vkliuchaet v sebia eto samoe, otritsaemoe im predlozhenie, (ili, sootvetstvenno, klass), to ono - istinno".
} 
however, is whether these contradictions are where Florensky says they are, that is, in the antinomy of the two laws (see 2.3) and in the doctrines of the Trinity and the incarnation (see 2.6). In order to accept these contradictions, Florensky would first have us accept that there can be such a thing as a "rationally obligatory" contradiction.

In this respect Florensky aligns himself with dialetheism, or "two-truth logic", which has over the past 20 years gained an increasingly dominant presence in contemporary philosophy, maintaining that the Law of Non-Contradiction need not be universally necessary for a coherent logic. Graham Priest, the most prominent figure of the movement, has developed such a paraconsistent logic which famously rejects Frege's insistence that there can be only two truth values, ${ }^{32}$ by allowing for a third value: "true and false". For this reason, paraconsistency is quite foreign to the Western philosophical community. The first problem with accepting a paraconsistent antinomism like Florensky's (or any of the following thinkers) is that, according to classical logic, it leaves open the possibility of accepting any contradiction, however obscure. Priest gives the example: "I am a fried egg" and "I am not a fried egg" (Priest 2004, p. 23). This is called the principle of explosion, or: Ex contradictione quodlibet. Priest however makes a sharp distinction between believing in some contradictions, and believing all contradictions. He defends, for example, some contradictions which are "rationally obligatory", such as the Liar Paradox ('This sentence is false') (Priest 2004, p. 23). Priest juxtaposes classical logic with a paraconsistent logic in which truth and falsity by interpretation are no longer "exclusive and exhaustive" but have significant overlap (Priest 2004, p. 26), as he represents in the following diagrams:

\footnotetext{
32 As Edward N. Zalta summarises, "The sentences of Frege's mature logical system are (complex) denoting terms; they are terms that denote truth-values. Frege distinguished two truth-values, The True and The False, which he took to be objects. The basic sentences of Frege's system are constructed using the expression ' ()$=()()=()$ ', which signifies a binary function that maps a pair of objects $x$ and $y$ to The True if $x$ is identical to $y$ and maps $x$ and $y$ to The False otherwise. A sentence such as ' $22=422=4$ ' therefore denotes the truth-value The True, while the sentence ' $22=622=6$ ' denotes The False" (Zalta 1995).
} 
Classical Logic:

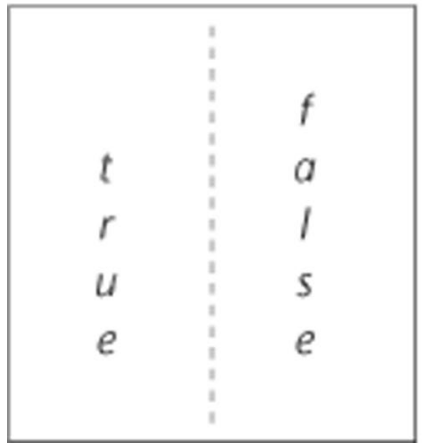

Paraconsistent Logic:

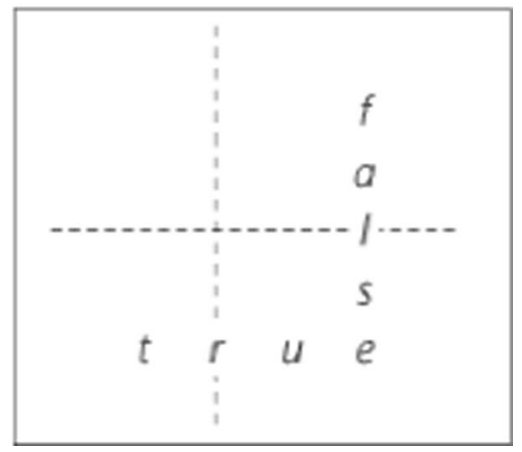

\section{Four Possible Readings of Florensky's Antinomism}

Reading Florensky paraconsistently assumes that the above schema is universal and thus antinomies are ubiquitous. This means antinomies are located both on the side of rationality (the horizontal) and higher reason (the vertical) and that, as Rojek writes, "Even in the state of enlightenment, the truths of religion remain inconsistent, only the attitude to them is changed" (Rojek 2019, p. 131). However, three other tendencies have emerged in Florensky scholarship. Some have claimed that horizontal rationality doesn't contain antinomies because it instinctively and perpetually solves them, and it is only the world of vertical reason (revelation) where antinomies appear. This is known as an L-inconsistent reading (the ' $\mathrm{L}$ ' stands for limit). In other words, there are only vertical antinomies, and no horizontal ones. This reading was championed by Viacheslav Moiseev (2001, pp. 329-39). ${ }^{33}$ Moiseev understands antinomies as "the limits of the infinite sequences of consistent rational formulas" (Rojek 2019, p. 133). Antinomies are constantly being solved by infinite rational solutions. Although antinomies do not exist horizontally, this infinite succession of solutions suggests a final vertical antinomy. In the same way that the infinity of 0.9 recurring "suggests" the completeness of the integer 1 .

Contrastingly, some readings suggest that antinomies are only really present in horizontal fallen rationality, but were "resolved" in the vertical (and therefore are no longer present). This is a non-monotonic interpretation. In other words, there are only horizontal antinomies, and no real vertical ones. Since this is a widespread reading, it is worth giving some detail. As the Russian logician Evgenii Sidorenko claimed, "Florensky put forward a number of ideas, which were made explicit in our times in the systems of non-monotonic logics" (Sidorenko 2002, p. 167). Sidorenko

\footnotetext{
33 Moiseev's study forms an analysis of the concept of "total-unity" through the lens of contemporary logic. This work is also available on the author's website: [http://www.vyacheslav-moiseev.narod.ru/ LogVs/LOGVS.pdf].
} 
and others base their arguments on Florensky's short addendum in The Pillar, which deals with Lewis Carrol's famous Barbershop Paradox. The Paradox imagined a hypothetical barbershop with three barbers, Allen, Brown and Carr. We accept the premises: one of them is always in the shop and Brown appears there only with Allen. We then are faced with the following two statements:

(1) If Allen is out, then Brown is out. (since Brown appears only with Allen)

(2) If Carr is out, then, if Allen is out, then Brown is in. (since one of them must be in the shop, this second statement however contradicts the premise that Brown appears only with Allen)

Or:

(1) $\mathrm{q} \rightarrow \mathrm{r}$

(2) $\mathrm{p} \rightarrow(\mathrm{q} \rightarrow \neg \mathrm{r})$

Florensky expresses this as "q implies $r$ (1), but p implies that q implies not-r (2), what should be concluded from this?". Florensky concludes that $\mathrm{p}$ is a sort of "leap of faith" which modifies the entire worldview. This modification of the entire worldview is identified as "spiritual illumination". Florensky now reads q as "the contradictions of Holy Scripture and dogma" and reads $r$ as "non-divine origin" (Florensky 1914 , p. 504). So the problem is reformulated as:

(1) If the Scripture is contradictory, then the Scripture is not-divine

(2) If there is spiritual illumination, then if the Scripture is contradictory, it must be divine

This unusual paradox is thus read non-monotonically, suggesting that a certain condition (p) can shift the entire logic and resolve its antinomies, in the same way that in monotonic logic "the extension of a set of premises may lead to the rejection of the previous conclusions" (Rojek 2019, p. 135).

Finally, some have even claimed that there are no antinomies in Florensky's work, and that antinomy and paradox are employed only rhetorically, for example Gerasimova (2012) and Slesinski (1984). These four readings can be summarized in the following table which has been modified from Rojek's chapter (2019, p. 129):

\begin{tabular}{|c|c|c|c|}
\hline Type of Interpretation: & Rationality (Horizontal): & Reason (Vertical): & Found in: \\
\hline paraconsistent & $\begin{array}{l}\text { inconsistent } \\
\text { (antinomies present) }\end{array}$ & $\begin{array}{l}\text { inconsistent } \\
\text { (antinomies present) }\end{array}$ & Michael Rhodes (2013) \\
\hline L-inconsistent & $\begin{array}{l}\text { consistent } \\
\text { (no antinomies present) }\end{array}$ & $\begin{array}{l}\text { inconsistent } \\
\text { (antinomies present) }\end{array}$ & Viacheslav Moiseev \\
\hline non-monotonic & $\begin{array}{l}\text { inconsistent } \\
\text { (antinomies present) }\end{array}$ & $\begin{array}{l}\text { consistent } \\
\text { (no antinomies present) }\end{array}$ & Evgenii Sidorenko \\
\hline rhetorical & $\begin{array}{l}\text { consistent } \\
\text { (no antinomies present) }\end{array}$ & $\begin{array}{l}\text { consistent } \\
\text { (no antinomies present) }\end{array}$ & Irina Gerasimova \\
\hline
\end{tabular}


The present study will support paraconsistent readings of antinomy throughout. This is because, as Florensky and many others have shown, antinomies not only occupy vertical theological religious discourse, but also linguistic, ${ }^{34}$ and aesthetic discourse. ${ }^{35}$ Both of the latter can be considered as belonging to the realm of horizontal antinomism. For Florensky therefore, antinomies are present both in the horizontal and in the vertical. A strictly paraconsistent reading of Florensky also makes perfect sense considering the development of Russian logic. Already by 1912, a few years before the publication of The Pillar, Nicolai Vasil'ev (1880-1940) had pioneered his own paraconsistent logic (Vasil'ev 1989), ${ }^{36}$ thus providing the perfect context for Florensky's work. Rojek himself opts for a combination of the nonmonotonic and the L-inconsistent readings. However, despite this original synthesis, Rojek does not factor in the broader horizontal antinomies (aesthetic and linguistic) or, most importantly, Florensky's central horizontal "antinomy of the two laws" and so understandably rejects a para-consistent reading outright. This latter horizontal antinomy is pivotal. It is more convincing than the "Logical Theory of Antinomy" which has been discussed up till now, and attempts to directly anticipate the doctrine of the Trinity. Like the "Logical Theory of Antinomy", however, the antinomy of the two laws will likewise prove unsatisfactory, since there is no direct continuity from the laws to the Trinity, and Florensky thus offers no reason why someone like a non-Christian would accept the Trinity. This antinomy will now be considered in detail.

\section{The Law of Identity}

For Florensky a genuinely rationalist ontology is exemplified by the formula $\mathrm{A}=\mathrm{A}$, known in classical logic as the Law of Identity. As Florensky writes, "That which is rational, which conforms to the measure of rationality and satisfies the demands of rationality, can only be that which is isolated from everything else, which is not

\footnotetext{
34 Florensky forms three antinomies of language. The second for example, the "antinomy of speech and intelligibility" claims that "a speaker's full intelligibility of his own words arises only when his speech becomes intelligible for others”. (Florensky 1996a, p. 144). On Florensky's antinomy of language see: Obolevitch (2014, pp. 150-153). Bulgakov will employ a similar antinomy of language in his Filosofia imeni which likewise opposes the individuality and the communality of language. On the one hand, the word has its "independent meaning" its "individual connotation" (sobstvennaia okraska), whilst on the other hand "the word has meaning only in its context, only as part of the whole" (Bulgakov 1953, p. 14).

35 This is most evident in Florensky's symbolic iconology. Firstly, the icon is that which is paradoxically more than itself, it is both that which it is, and also more than that which it is: "A symbol is something that manifests in itself that which is not itself, that which is greater than itself and is nevertheless manifested through itself". Florensky reflects on this further in his Iconostasis and formulates the analogy of a window. A window at first glance, is simply wood and glass. But when we begin to perceive light shining through it, the window ceases to be simply a window, but paradoxically becomes the very light itself (Florensky 1985, p. 222). The second area of antinomy in the icon is what Florensky refers to as "mutually contradictory details of icon drawing", (vzaimno protivorechivye podrobnosti risunka). He mentions for a start the dynamic play of light in the icon, which often seems to have no noticeable source (the technique of chiaroscuro) and describes this as "contradictory illuminations in different parts of the icon, the tendency to project forward masses which should be in shadow" (Florensky 1999, p. 49).

${ }^{36}$ For an English introduction to Vasil'ev's work see: Raspa (2017).
} 
mixed with anything else, which is self-contained, in short, which is self-identical" (Florensky 1914, pp. 28-29). ${ }^{37}$ Florensky would continue to reflect on the Law of Identity throughout his life, and by the time of his later lectures he would come to associate the law disparagingly with "western European thought" (Florensky 2014, p. 131). This law is indeed still a pillar of veracity in classical logic, as Paul Tomassi writes:

There is no possible interpretation under which the [Law of Identity] is false. If it's raining then it's raining, if the sun is shining then the sun is shining. And so on, ad nauseam. The very form of this formula ensures that no matter how we translate or interpret its constituent sentence-letters it will always be true. Hence, the law of identity is a logical truth. (Tomassi 1999, p. 67)

According to the Russian polymath, however, the law is stagnant and lifeless since it does not account for the real non-identity present in the mutable flux of life itself. The Law of Identity is a 'hypostasised abstraction' for Florensky (1914, p. 28). ${ }^{38}$ Most importantly, Florensky believed that $\mathrm{A}=\mathrm{A}$ was not only an abstraction but was a fundamentally negative definition, which operates according to the exclusion of alterity. Florensky writes:

In excluding all the other elements, every $\mathrm{A}$ is excluded by all of them, for if each of these elements is for A only not-A, then A over against not-A is only not-not-A. From the viewpoint of the Law of Identity, all being, in desiring to affirm itself, actually only destroys itself, becoming a combination of elements each of which is a centre of negations, and only negations. Thus all being is a total negation, one great 'Not'. The Law of Identity is the spirit of death, emptiness, and nothingness. (Florensky 1914, p. 27)

Absolute silence is characteristic of this law, since the sterile $\mathrm{A}=\mathrm{A}$ cannot be explained any further, for then A would equal a certain 'not-A', and the law would already be broken. Furthermore, as Schneider points out, there is no reason as to why we should even accept the law as access to certitude, as it is pure intuition: "The perception of a being in intuition does not provide the human mind with reasons for why it should accept this intuition as an experience of the Truth" (Schneider 2019, p. 6).

Due to the ever-changing nature of the universe, there is for Florensky no real identity in the world of things, only a sort of 'self-similarity', which can be

\footnotetext{
37 "Rassudochno, t..e. soobrano mere rassudka, vmestimo v rassudok, otvechaet trebovaniiam rassudka, lish' to, chto vydeleno iz sredy prochego, chto ne smeshivaet s prochim, chto zamknuto v sebia, odim slovom, - chto samo-tozhdestvenno".

38 "Ipostasirovannoe otvlechenie".

39 "Kazhdoe A, iskliuchaia vse prochie elementy, iskliuchaetsia vsemi imi; ved' esli kazhdyi is nikh dlia A est' tol'ko ne-A, to i A suprotiv ne-A est' tol'ko ne-ne-A. Pod uglom zreniia zakona tozhdestva, vse bytie, zhelaia utverzhdat' sebia, na dele tol'ko iznichtozhivaet sebia, delaias' sovokupnost'iu takikh elementov, iz kotorykh kazhdyi est' tsentr otritsanii i, pri tom, tol'ko otritsanii; takim obrazom, vse bytie iavliaetsia sploshnym otritsaniem odnim velikim 'ne'. Zakon tozhdestva est' dukh smerti, pustoty i nichtozhestvo".
} 
understood only by analogy with the identity of the human self. True identity is found only in the self-identity of the subject. As Florensky writes: "Philosophers of the most different orientations have repeated the basic theme that the idea of identity in general is the reflection of the self-identity of the 'I' ... identity in its authentic and primary sense can be perceived only in the self-identity of the person and not in the self-similarity of the thing" (Florensky 1914, p. 82). ${ }^{40}$ The subject is thus that which is most identical with itself. In this respect, Florensky quotes the neo-Kantian philosopher Herman Cohen: "die Selbigkeit des Seins ist ein Reflex der Identität des Denkens" (Florensky 1914, p. 82). ${ }^{41}$ The author of The Pillar is thus justified to translate the Law of Identity, $A=A$, into Fichtean subjectivist terms: ' $I=I$ '. This leaves us not just with stagnancy, but an ethically undesirable 'cry of naked egoism', a negation of all other 'I''s (Florensky 1914, p. 78), ${ }^{42}$ what Bruce Foltz calls a "prison of self-affirmation and self-assertion" (Foltz 2013, p. 8).

All of these problems with the Law of Identity stem from another law which is embedded within human reasoning. This is the perpetual desire to provide an account for some state of affairs 'from outside'. This is a drive for a final ground or justification which is not identical with that which is being justified. This is The Law of Sufficient Reason.

\section{The Law of Sufficient Reason}

The Law of Sufficient Reason, another central feature of classical logic, states the following: "For every $\mathrm{x}$ there is a $\mathrm{y}$, such that $\mathrm{y}$ is the sufficient reason for $\mathrm{x}$ ". This means for Florensky the search for a "grounding judgement" (Florensky 1914, p. $80) .{ }^{43}$ But to avoid pure givenness this judgement must be justified in another which in turn must be justified in another ad infinitum. This 'never ending fall into infinitude' is identified with the Hegelian bad infinity of the Verstand. ${ }^{44}$ This type of certitude Florensky names 'discursive certitude' in contradistinction to the 'intuitive certitude' discussed above. The Russian polymath claims that the whole essence of this discursive certitude, its entire 'reasonableness', is contained in the constant transmission from $n$ to $(n+1)$ (Florensky 1914, p. 81). This sort of certitude "only gives rise in time to the dream of eternity but never makes it possible to touch eternity

\footnotetext{
40 “Povtorialas' filosofami samykx razlichnykh napravlenii ta osnovnaia tema, chto ideia tozhdestva voobsche est' otrazhenie samo-tozhdestvo ia... chto tozhdestvo v sobstvennom i pervichnom smysle mozhet byt' usmatrivaema lish' v samo-tozhdestve lichnosti, a ne v samo-podobii veschi”.

41 Albertini (2003) nicely summarises Cohen's position in the following: "Für Cohen ist die Identität eine Denkbestimmung, die Identität von Denken und Sein, bzw. die Identität des Seins hat ihre Basis in der Identität des Denkens" (33).

42 "Krik obnazhennogo egoizma".

43 "Obosnovyvaiuschee suzhdenie".

44 Hegel's "true infinity", as Michael Inwood explains, is "any relatively self-contained reciprocal or circular structure, in contrast to an endless advance from one thing to another, e.g. three mutually supporting inferences in contrast to a bad infinite series of inferences; the reciprocal involvement of cause and effect in contrast to an infinite series of causes and effects; the spirit of self-consciousness that is not limited by its other but at home in it". (Inwood 1992, p. 141).
} 
itself" (Florensky 1914, p. 31). ${ }^{45}$ In defence of this law, Florensky once again turned to his rival Kant, who understood that in order to explain a given phenomenon, we can only use other given phenomena in a continuous successive manner (Schneider 2019, p. 6).

Florensky now contrasts the former Law of Identity with the latter Law of Sufficient Reason. The former is identified with intuition, while the latter is identified with discourse. In an important passage of The Pillar and Ground of the Truth, we read the following: "If the former [Law of Identity] provides non-philosophical satisfaction by its presence and its reliability, the latter [Law of sufficient Reason] is, in fact, not attained reasonableness but only a regulating principle, a law for the activity of reason, a road on which we must walk eternally in order to never reach any goal. A reasonable criterion is a direction, not a goal" (Florensky 1914, p. 32). ${ }^{46}$ The two laws thus contradict each other, are in antinomy with one another, as the "Scylla and Charybdis on the way to certitude" (Florensky 1914, p. 33). ${ }^{47}$

\section{The 'Perichoretic Reconfiguration'}

As an alternative to a violent opposition of the two laws, Florensky endorses a turn to reason (razum), or more precisely "higher reason", a term which had already become important for other Russian intellectuals, notably Nikolai Berdyaev. ${ }^{48}$ Florensky's "higher reason" is essentially the vertical antinomism of the Trinity. As Schneider has shown, this is reached through a "perichoretic reconfiguration" of the two laws discussed above. This is an attempt to show that they anticipate the real (vertical) antinomies in the Trinity. Initially, the Law of Identity is reconfigured and $\mathrm{A}=\mathrm{A}(\mathrm{I}=\mathrm{I})$ is now understood as an "act of self-emptying" which allows A to receive itself only through another (B) in virtue of its own (A's) self-rejection. In other words, the Father kenotically receiving himself in the Son. This now allows for the possibility of B to be included in the relationship of identity. This is an inclusion of the other in the self, and simultaneously the inclusion of the self in the other. As Schneider writes, "Identity is now based on a kenotic and perichoretic act of selfemptying and self-rejection, which at the same time enables a person or being (say A) to receive itself back in its self-rejection from another (say B)" (Schneider 2019, p. 9). The Law of Identity is thus seen as anticipating the Father-Son relationship.

Not only the Law of Identity but also the Law of Sufficient Reason is remarkably reconfigured in the Trinity as a "self-proving subject" (Foltz 2013, p. 16). Florensky

\footnotetext{
$\overline{45}$ “Razumnoe dokazatel'stvo tol'ko sozdaet vo vremeni mechtu o vechnosti, no nikogda ne daet kosnut'cia samoi vechnosti".

46 "Esli pervaia dostavliala nefilosofskoe udovletvorenie svoeiu nalichnost'iu, svoeiu nadezhnost'iu, to vtoraia fakticheski byvaet nedostupnoi razumnost'iu, no lish' reguliativnym printsipom, pravilom deiatel'nosti razuma, dorogoiu, po kotoroi oni dolzhny vechno idti, chtoby... chtoby nikogda ne priiti ni k kakoi tseli".

47 "Konechnaia intuitsia i bezgranichnaia diskursia - vot ctsilla i kharibda na puti k dostovernosti".

48 See for example Berdyaev's Filosofia Svobody where we read the following: "Reason ought to reduce its isolation, its truncated existence and organically unite itself with the integral life of the spirit, only then is reasonable knowledge (poznanie) possible, in a higher sense" (Berdyaev 1911, p. 20).
} 
begins by reminding us that according to the Law of Sufficient Reason, the reason/ principle of A must be found in something else, in another phenomenon (B). However, if B is merely defined as not-A, then B's own "finding of itself" in another would just lead to not-not-A (which is equal to A), meaning that $\mathrm{A}$ has never left itself at all. In trying to find its ground in another, A has not actually managed to escape itself, since its other is only its own negation, and the negation of that negation leads back to itself. So, B must be something more than merely not-A. B can achieve this status of being more that not-A only by being "not- (something else)", or "not- (some third term)". B must, therefore, be understood as a not-C. Now since we have arrived at a third term "C", this $\mathrm{C}$ must itself find a ground. It must find a not-C which is not simply B as not- $\mathrm{C}$ (as then the ground of that B would lead us to not-not-C, and $\mathrm{C}$ would not have escaped itself). C must find B also as a "not- (some third term)", a role which can be filled by A. A can thus "receive itself mediately from another, but not through the one with which it is equated" (Florensky 1914, p. 48). ${ }^{49}$

By considering discursion based only on three terms A, B, C, which ground each other, Florensky believes, the endless searching of the Law of Sufficient Reason is no more, "through $\mathrm{C}$ the circle can be closed", and here "A receives itself as proved, already established" (Florensky 1914, p. 48). ${ }^{50}$ We now have, in Schneider's words, an "infinite, dynamic, but circular movement between A, B, and a third (C)" (Schneider 2019, p. 9). A, B, and C must also be subjects, in virtue of their authentic self-identity. Florensky has thus demonstrated "the contemplation of oneself through another in a third: Father, Son and Spirit" (Florensky 1914, p. 48). ${ }^{51}$ The potential, or 'bad' infinity which characterised the Law of Sufficient Reason, is now "fully delimited and determinate" (Schneider 2019, p. 11). Although this reconfiguration of the two laws may seem like a rationalist deduction of the Trinity, much in the tradition of Solov'ev, Schneider insists that Florensky is actually constructing an "exposition of the content of the already given Truth", or more precisely, "a formal anticipation of the Truth". (Schneider 2019, p. 8)

We could thus read the above antinomy of the two laws as a horizontal antinomy which anticipates a vertical antinomy (the Trinity). However, there are serious problems with this "purely logical" anticipatory path from the horizontal to the vertical. Firstly, as Adam Drozdek points out, there is no real contradiction between the two laws. $\mathrm{A}=\mathrm{B}$ (the supplying of a reason for $\mathrm{A}$ through predication of $\mathrm{A}$ ) does not have to contradict $A=A$, because $A=B$ can simply mean that $A$ is just an element in the set B, or that A is a subset of set B (Drozdek 2008, p. 180). Drozdek thus concludes with the following: "If the necessary antinomic nature of reason is a reality, it is not based on the clash between the law of identity and the law of sufficient reason" (Drozdek 2008, p. 180). In other words, Florensky "failed to show the inescapably antinomic nature of reason [and its two laws]" (Drozdek 2008, p. 182).

\footnotetext{
49 'A ot drugogo, no ne ot togo, kotoromu priravnivaetsia, t. e. ot B, oposredstvovanno poluchaet sebia'.

50 'Cherez B krug mozhet zamknut'sia... [A] poluchaet cebia, no uzhe 'dokazannym', uzhe ustanovlennym'.

51 'Sozertsanie Sebia cherez Drugogo v Tret'em: Otets, Syn, Dukh'.
} 
Florensky, additionally, simply assumes that explicit talk of the doctrine of the Trinity has relevance for logic and thus for human thought, when there is really no "continuity" between the doctrine and the laws of logic. Schneider is aware of this and admits that a certain "discontinuity" is present in the anticipatory leap from the horizontal world of terms, principles and subjects (A, B and C) to the vertical world of the Father, the Son and the Holy Spirit. The Russian philosopher thus relies on a "leap of faith" or (podvig), which is required to pass over to the vertical world of the Trinity. Despite his enthusiasm for the "perichoretic reconfiguration", Schneider eventually admits that the anticipation leaves us with "no positive evaluation of the laws themselves" (Schneider 2019, p. 16). In other words, the synthesis is "incompatible with normal laws of rationality" (Schneider 2019, p. 16). Schneider admits that the perichoretic reconfiguration is too far removed from rationality (rassudok), and the leap from this horizontal rationality to the vertical reason of the "perichoretic reconfiguration" is too great. Schneider even senses a "tendency to regard univocal logic as something inherently sinful and problematic" (Schneider 2019, p. 15). This tendency would find advocates in later Orthodox theology (Lossky 1991, p. 65).

The anticipation of vertical antinomism within horizontal antinomism is thus ultimately thwarted with discontinuity. Florensky clearly attempted such an anticipation through logic alone, neglecting other horizontal antinomies, such as ontological and aesthetic antinomies, which are only developed by later thinkers (Aleksei Losev in particular) and provide surer foundations for an anticipation of the vertical. Despite the failed horizontal antinomy, and with this, his failed attempt to convince his readers, Florensky nonetheless provided a rich account of the vertical antinomies of dogma and scripture which deserves some attention. These antinomies are those of faith, antinomies isolated from horizontal justification, one either accepts such contradictions or rejects them.

\section{A Defence of Dogmatic Antinomism}

Florensky claims that "only genuine religious experience apprehends antinomies and sees how their factual reconciliation is possible" (Florensky 1914, p. 162). ${ }^{52}$ This may cause some concern since surely anyone can "apprehend" antinomic dogma without any experience of it. Of course, one can "apprehend" the dogmas, but this is different from having faith in them, which is what Florensky means here. As has been shown above, Florensky does not justify or sufficiently warrant this faith with his antinomism, and thus falls into fideism - faith arises in personal experience which we cannot explain. These problems should not distract us from the purely theological place of paradox. As Christians, Florensky insists, we must practise an ascetic "taming of rational activity" (Florensky 1914, p. $161),{ }^{53}$ and it is precisely dogma which nurtures this experience and "tames" the

\footnotetext{
52 “Tol'ko podlinnyi religioznyi opyt usmatrivaet antinomii i vidit, kak vozmozhno fakticheskoe ikh primirenie".

53 "Ukroschenie svoei rassudochnoi deiatel'nosti".
} 
intellect. In Florensky's view dogmatics must preserve a fundamental paradox in order to elicit freely-willed faith, as opposed to forced deduction. Florensky lists a total of eleven dogmatic antinomies to illustrate this point, including the trinitarian antinomy (God as both "consubstantial", and "tri-hypostatic") and the two natures of Christ (both "unmerged" and "indivisible") (Florensky 1914, p. 164).

Such an antinomian approach to dogmatics is not without criticism. The most famous attack was launched by the philosopher and prince, Evgeniy Trubetskoi (1863-1920) in his essay "The Light of Tabor and the Transfiguration of the Mind" (Trubetskoi 2015). In Trubetskoi's understanding, dogma is far from antinomic, since only a Solov'evian "whole" and a cohesive Christianity unites all aspects of life in all-unity (vseedinstvo) (Trubetskoi 2015, p. 8). Trubetskoi sees reason itself as participating in the transfiguration of mount Tabor (Trubetskoi 2015, p. 9), and holds that Florensky is a fideist who by separating faith from reason allows for an 'autonomous reason' and a wildly irrational faith.

According to Trubetskoi, Florensky has confused contradiction (protivorechie) with opposition (protivopolozhenie) (Trubetskoi 2015, p. 14), and Christian dogmas are marked only by the latter, not the former. Antinomy only arises when one admits "contradictory predicates concerning the same subject according to the same relation" (Trubetskoi 2015, p. 14). Therefore dogmas such as the Trinity are not really antinomies. Here the predication of "unity" applies only to the subject "Ousia", while the predication of "multiplicity" applies only to the subject "Hypostases". Similarly, when addressing Christology, Trubetskoi writes that inseparability (nerazdel'nost') and non-confusability (nesliiannost') do not logically exclude one another (Trubetskoi 2015, p. 14). Trubetskoi also claims that it is only our own fallen and insufficient intellects which are faced with antinomies. We can, and should, rise above antinomies and aim for their resolution (razreshenie) (Trubetskoi 2015, p. 15). We should aim for the "true and authentic norm of reason", which is for the Russian prince cohesion and unity (Trubetskoi 2015, p. 15). Trubetskoi can, in this way, be considered as an early adherent of nonmonotonic readings of Florensky's Pillar.

Despite his efforts, Trubetskoi fails to notice Florensky's overall project in The Pillar (however unsuccessful this may have been) of revealing an antinomy between the two laws of logic which ought to anticipate the higher antinomy of the Trinity. This is itself a cognitive enterprise of reason (however unsuccessful) and can itself be considered as the sort of "transfiguration of the mind" which Trubetskoi sought. More importantly, however, Trubetskoi does not properly consider the paradoxes of Christian dogma. Although he is correct that God is one qua Ousia and three qua Hypostases, Trubetskoi ignores the fact that the Hypostases are numerically identical with the Ousia yet remain in complete nonidentity with each other. Simply put: (1) There is only one divine being and (2) there are three divine beings, is indeed a logical contradiction, more precisely an antinomy of identity and difference. This is spelled out in recent philosophy of religion, specifically by James Anderson in his comprehensive Paradox in Christian Theology (2007). Here Anderson distils the historical formulation of the Trinity into 6 consecutive theses, clarifying the antinomy. 
“(T1) An orthodox doctrine of the Trinity must uphold biblical monotheism: there can only be one absolute, transcendent, indivisible, sovereign God. (Hence, all forms of polytheism should be excluded).

(T2) An orthodox doctrine of the Trinity must maintain the full and equal divinity of each of the three persons: the Father is fully God, the Son is fully God, and the Spirit is fully God. (Hence, all forms of ontological subordinationism should be excluded).

(T3) An orthodox doctrine of the Trinity must posit genuine distinctions between the three persons: The Father is not the same as the Son or the Spirit, and the Son is not the same as the Spirit. (Hence all forms of modalism should be avoided).

(T4) On the one hand, the conjunction of (T1) and (T2) seems to require that the consubstantiality relation between the divine persons be construed in terms of numerical identity rather than generic identity: The Father is identical with, not distinct from, the one divine ousia (essence, substance, Godhead); likewise, for the Son and the Spirit.

(T5) On the other hand, (T3) seems to require that each divine person is numerically distinct from (i.e., not numerically identical to) each of the other two persons.

(T6) Consequently, any interpretation of the doctrine of the Trinity that seeks to fulfil requirements (T1), (T2), and (T3) will be paradoxical, given our natural intuitions about the concepts employed" (Anderson 2007, p. 30).

Anderson concludes his history of the Trinity with the following: "There appears to be no option for the Christian theologian but to grasp one or the other horn of the dilemma: to abandon orthodoxy or to embrace paradox and thereby face the charge of irrationality" (Anderson 2007, p. 106).

Although there is a clear antinomy in the dogma of the Trinity, many are still hesitant to accept any sort of vertical antinomism. Drozdek, building on Trubetskoi, writes: "If all religious mysteries could only be clothed in contradiction, then we can say that God exists and does not exist" (Drozdek 2008, p. 182). In other words, why are not all dogmas self-contradictions? But in response to such a problem, it seems that the existence of God is not a linguistically defined theological dogma (in the same way that the Trinity and the Incarnation are) but is dependent on the entire dogmatic system of Orthodoxy as a whole. It is therefore not necessary that all religious statements are antinomies. Thus, it would seem that Florensky was right to assert that there are at least some religious vertical antinomies which are properly logically contradictory. These are central and dogmatic antinomies, whose antinomicity emanates as a general "paradoxical pathos", as witnessed by the many scriptural and liturgical juxtapositions which pervade the life of the Church. Many of these juxtapositions are summarized in the idea, central to Christian life, that glorification arises only through its opposite, humiliation (Matthew 20:16). 


\section{Conclusion}

This study has provided some necessary context for the emergence of Russian antinomism, highlighting the influence of German Idealism. The key methodological distinction was then drawn between horizontal and vertical antinomy. This allows us to see how the Russian philosophers in question sought to anticipate the later in the former. The religious-philosophical insights of Pavel Florensky were then addressed, incorporating the most recent and most pertinent critiques and readings of Florensky's antinomism. Initially, the four possible readings of Florensky's philosophy of contradiction were outlined, to suggest that a paraconsistent reading is most suitable. Florensky's "Logical Theory of Antinomy" was shown to be highly problematic. This theory however should not be seen as the author's central argument. The latter is contained in Florensky's "perichoretic reconfiguration" of the laws of identity and sufficient reason. It was, however, concluded that even this sophisticated reconfiguration failed to anticipate the vertical in the horizontal, exhibiting too great a leap from rational laws to Trinitarian dogma. Although Florensky did not justify his entry into the world of faith and theology, once within that world paradoxes certainly abound.

As mentioned above, antinomism received further development in the work of Sergei Bulgakov, and was brought to its culmination in the writings of Aleksei Losev. Unlike Florensky these thinkers do not restrict antinomism to purely logical categories, but engage closely with horizontal antinomies of aesthetics, language and subjectivity. Despite the shift in focus in these thinkers, one can, of course, maintain a continued tradition of antinomic speculation throughout Russian intellectual history. These treatments, however, must remain for now beyond the scope of the present study.

\section{Compliance with Ethical Standards}

Conflict of interest On behalf of all authors, the corresponding author states that there is no conflict of interest.

Open Access This article is licensed under a Creative Commons Attribution 4.0 International License, which permits use, sharing, adaptation, distribution and reproduction in any medium or format, as long as you give appropriate credit to the original author(s) and the source, provide a link to the Creative Commons licence, and indicate if changes were made. The images or other third party material in this article are included in the article's Creative Commons licence, unless indicated otherwise in a credit line to the material. If material is not included in the article's Creative Commons licence and your intended use is not permitted by statutory regulation or exceeds the permitted use, you will need to obtain permission directly from the copyright holder. To view a copy of this licence, visit http://creativecommons.org/licen ses/by/4.0/.

\section{References}

Albertini, F. (2003). Das Verständnis des Seins bei Hermann Cohen: Vom Neukantianismus zu einer jüdischen Religionsphilosophie. Würzburg: Verlag Königshausen \& Neumann. 
Anderson, J. (2007). Paradox in Christian Theology: An analysis of its presence, character, and epistemic status. Milton Keynes: Paternoster.

Astapov, S. (2009). Antinomiia v otritsatel'noi dialektike P.A Florekskogo, S.N Bulgakova, S.L Franka. Nauchnaia Mysl' Kavkaza, 1, 54-58.

Bakhtin, M. (1984). Problems of Dostoevsky's poetics. Minneapolis: University of Minnesota Press.

Berdyaev, N. (1911). Filosofia Svobody. Moscow: Put'.

Berdyaev, N. (1938). Osnovnaia ideia filosofii L'va Shestova. Put', 58, 44-48.

Berdyaev, N. (1989). Sobranie Sochinenii (Vol. 3). Paris: YMCA-Press.

Biriukov, D. (2010). Trudnye Vremena Filosofii. Iurii Alekseevich Gastev: Filosofsko-Logicheskie Raboty I 'Dissidentskaia Deiatelnost'. Moscow: Librokom.

Blank, K. (2007). The rabbit and the duck: Antinomic unity in Dostoevskij, the Russian religious tradition, and Mikhail Bakhtin. Studies in Eastern European Thought, 59, 21-37.

Bulgakov, S. (1953). Filosofiia imeni. Paris: YMCA-Press.

Bulgakov, S. (1994). Svet Nevechernii: Sozertsaniia i Umozreniia. Moscow: Respublika.

Coates, R. (2010). Religious renaissance in the silver age. In W. Leatherbarrow \& D. Offord (Eds.), A history of Russian thought (pp. 169-193). Cambridge: CUP.

Cohen, M. H. (1962). The aporias in Plato's early dialogues. Journal of the History of Ideas, 23, 163-174.

Drozdek, A. (2008). Defying rationality: Florensky and Frank. Poznanskie Studia Teologiczne, 22, $175-188$.

Florensky, P. (1914). Stolp i utverzhdenie istiny: opyt pravoslavnoi teoditsei v dvenadtsati pis'makh. Moscow: Pyt'.

Florensky, P. (1985). Ikonostas. Sobranie sochinenii i stat'i po iskusstvu (pp. 193-317). Paris: YMCA-Press.

Florensky, P. (1996a). Antinomiia Iazyka. Sobranie sochinenia v chetirekh tomakh (Vol. 3, pp. 141-184). Moscow: Mysl'.

Florensky, P. (1996b). Imeslavie kak filosofskaia predposylka. Sochinenie v chetirekh tomakh (Vol. 2, pp. 281-321). Moscow: Mysl'.

Florensky, P. (1996c). Kosmologicheskie antinomii I. Kanta. Sochinenie v chetirekh tomakh (Vol. 2, pp. 3-33). Moscow: Mysl'.

Florensky, P. (1997). The pillar and ground of the truth: an essay in orthodox Theology in twelve letters trans. Boris Jakim. Princeton: Princeton University Press.

Florensky, P. (1999). Obratnaiia perspektiva. Sochenenie v chetyrekh tomakh v 3 (pp. 46-98). Moscow: Mysl'.

Florensky, P. (2010). For my children. In A. Pyman (Ed.), Pavel Florensky, A quiet genius: The tragic and extraordinary life of Russia's unknown da Vinci (p. 9). New York: Continuum.

Florensky, P. (2014). At the crossroads of science and mysticism trans. Boris Jakim. New York: Angelico Press.

Florovsky, G. (1989). The weariness of the spirit: On Florensky's. The pillar and confirmation of truth. In R. Haugh (Ed.), Philosophy and philosophical movements. Buchvertriebsanstalt: Vaduz.

Florovsky, G. (1998). Istoricheskie prozreniia Tyutcheva. In M. A. Kolerov \& Iu P Senokosov (Eds.), Iz proshlogo russkoi mysli (pp. 223-235). Moscow: Agraf.

Foltz, B. (2013). The fluttering of autumn leaves: Logic, mathematics, and metaphysics in Florensky's the pillar and ground of the truth. Studia Humana, 7, 3-18.

Frank, S. (1983). The unknowable: An ontological introduction to the philosophy of religion. Ohio: Ohio University Press.

Gallaher, B. (2012). Antinomism, trinity and the challenge of Solov'evan Pantheism in the Theology of Sergij Bulgakov. Studies in Eastern European Thought, 64, 205-225.

Gerasimova, I. (2012). Florenskii o protivorechii (logiko-metodoligicheskii analiz). Logicheskie Issledovaniia, 1, 77-96.

Harte, V. (2008). Plato's Metaphysics. In G. Fine (Ed.), The Oxford handbook of Plato (pp. 191-216). Oxford: OUP.

Hegel, G. W. F. (1975). Encyclopedia of the philosophical sciences trans. William Wallace. Oxford: Clarendon Press.

Hemmerle, K. (1992). Thesen zu einer trinitarischen Ontologie. Einsiedeln: Johannes Verlag.

Husserl, E. (1991). On the phenomenology of the consciousness of internal time (1893-1917) (trans. John Brough). Dordrecht: Kluwer.

Inwood, M. (1992). A Hegel dictionary. Malden: Blackwell.

Kant, I. (1956). Kritik der reinen Vernunft. Frankfurt: Suhrkamp. 
Kant, I. (2007). Critique of pure reason. London: Penguin.

Khoruzhii, S. (2010). Slavophiles, westernizers, and the birth of russian philosophical humanism. In G. M. Hamburg and Randall A. Poole (Eds.). A history of Russian philosophy 1830-1930: Faith, reason, and the defence of human dignity (pp. 27-51). Cambridge: CUP.

Lossky, N. (2018). Istoriia Russkoi Filosofii. St Petersburg: Azbuka.

Lossky, V. (1991). The mystical theology of the Eastern Church. Cambridge: James Clarke and Co.

Moiseev, V. (2001). Logika Vseedinstva. Voronezh: V. Moiseev.

Nicholas of Cusa. (1981). De Doctora Ignorantia. Minneapolis: The Arthur J. Banning Press.

Obolevitch, T. (2014). Ot imiaslaviia $k$ estetike. Kontseptsiia simvola Alekseia Loseva. Istoriko-filosofskoe issledovanie. Moscow: BBI.

Plato. (1997). The republic. In M. J. Cooper (Ed.), Plato: Complete works (pp. 971-1224). Cambridge: Hackett Publishing Company.

Priest, G. (2004). The law of non-contradiction: New philosophical essays. Oxford: OUP.

Pyman, A. (2010). Pavel Florensky, A quiet genius: The tragic and extraodinary life of Russia's unkown da Vinci. New York: Continuum.

Raspa, V. (2017). Thinking about contradictions: The imaginary logic of Nikolai Aleksandrovich Vasil'ev. Cham: Springer International Publishing.

Rhodes, M. (2013). On contradiction in orthodox philosophy. In A. Schumann (Ed.), Logic in orthodox Christian thinking (pp. 82-103). Heusenstamm: Ontos Verlag.

Rojek, P. (2019). Orthodoxy and logic: The case of Pavel Florensky's theory of antinomy. In C. Schneider (Ed.), Theology and philosophy in Eastern Orthodoxy: Essays on orthodox christianity and contemporary thought (pp. 120-144). Eugene: Wipf and Stock.

Schneider, C. (2019). Experiential doctrine and doctrinal experience in the religious epistemology of Pavel A. Florensky, paper given at Unfading Light: Conference on Creativity and Prayer in 20th Century Russian Orthodoxy, 7/3/2019, Oxford.

Schneider, C. (2020). Pavel A. Florensky: at the boundary of Immanence and Transcendence. In G. Pattison \& C Emerson (Eds.) The Oxford handbook of Russian religious thought. Oxford: OUP.

Sidorenko, E. (2002). Logistika i Teoditseia. In Sidorenko (Eds.) Logika. Paradoksy. Vozmozhnye miry. Razmyshleniia o myshlenii v deviati ocherkakh (pp. 184-220). Moscow: Editorial URSS.

Slesinski, R. (1984). Pavel Florensky: A metaphysics of love. New York: SVS.

Smith, J. (2020). Phenomenology. In Internet encyclopedia of philosophy: A peer-reviewed academic resource. https://iep.utm.edu/phenom/.

Solov'ev, V. (1948a). Lectures on Godmanhood trans. Peter Zouboff. London: Dennis Dobson.

Solov'ev, V. (1948b). Russia and the Universal Church trans. Herbert Rees. London: The Centenary Press.

Taylor, C. (1975). Hegel. Cambridge: CUP.

Tomassi, P. (1999). Logic. London: Routledge.

Trubetskoi, E. (2015). Svet Favorskii i Preobrazheniia Uma. In Florensky, P. V. (Ed.) Pavel Alexandrovich Florensky: Dialog so Vremenem. Svet Favorskii. Poetika Sud'by. Moscow: Russki Mir.

Usric, M. (1998). Paraconsistency and dialectics as Coincidentia Oppositorum in the philosophy of Nicholas of Cusa. Logique et Analyse, 41, 203-217.

Vasil'ev, N. (1989). Logika i metalogika. Izbrannie Trudy (pp. 94-123). Moscow: Nauka.

Vysheslavtsev, B. (1994). Etika preobrazhennogoeErosa. Moscow: Respublika.

Zalta, E. N. (1995) Gottlob Frege. In Stanford encyclopaedia of philosophy. https://plato.stanford.edu/ index.html.

Zenkovsky, V. (1953). A history of Russian philosophy (Vol. 2). London: Routledge.

Zernov, N. (1963). The Russian religious renaissance of the 20th century. London: Darton, Longman \& Todd.

Publisher's Note Springer Nature remains neutral with regard to jurisdictional claims in published maps and institutional affiliations. 